\title{
Impact of the Management of Work Environmental Hazards on the Perceived Quality of Occupational Health and Safety among Operational Employees in Construction Industry
}

\author{
Udaya Mohan Devadass ${ }^{1}$ and M. A. L. S. Wijesooriya ${ }^{2}$ \\ ${ }^{1}$ Department of Human Resource Management, Faculty of Commerce and \\ Management Studies, University of Kelaniya, Sri Lanka \\ ${ }^{2}$ Postgraduate, Faculty of Graduate Studies, University of Kelaniya, Sri Lanka
}

\begin{abstract}
The construction industry is one of the most hazardous industries in a country due to the nature of the products and the processes involved. In Sri Lanka, the construction industry plays a major role in the national economy. However, the prevention of such work environmental hazards still needs more attention in the construction field. The field currently reports a high level of accidents on construction sites that are either major or minor. Further, environmental hazards in the construction field in Sri Lanka have not been sufficiently studied empirically. Hence, this study was conducted to assess the work environmental hazards and their impact on the perceived quality of occupational health and safety among construction employees in the construction industry in Sri Lanka. The researchers used the quantitative survey method for this study on a sample of 154 construction employees, randomly selected. Correlation and regression analysis were utilized as the data analysis methods. The findings revealed that the management of environmental hazards have a significant positive impact on operational employees' perception of the quality of health and safety. The authors highlighted possible behavioral issues of employees such as retention issues if managers are not seriously committed towards improving the quality of their health and safety management practices. Towards this end, among other directions, the researchers highlighted implications to policy, practice, and research with suggestions for empowering HRM in the industry, following best practices, and pursuing innovative and varied research qualitatively and quantitative to study the phenomena in a more context based manner.
\end{abstract}

Keywords: Health and Safety, Operational Employees, Construction Industry, Occupational Accidents, Occupational Diseases, Quality of Work Life, Occupational Stress

\section{Introduction}

Construction has been regarded as the most hazardous industry to work in, since it is associated with a high level of health and safety risks (ILO, 2011; Deacon and Smallwood, 2017). The International Labour Organization (ILO) (2021) estimates that around 2.3 million women and men around the world become victims to work-related accidents or diseases every year; 6000 deaths every single day; around 340 million occupational accidents; and 160 million victims of work-related illnesses annually. ILO (2021) further reports the construction industry 
records disproportionately high rate of recorded accidents, and it has been about $25 \%$ to $40 \%$ of deaths in 2011 (ILO, 2011). As per the data in relation to deaths, various countries have pointed out that this industry generates $30 \%$ of deadly accidents in the industry within the European Union (EU) (Darshana, 2017) though, only $10 \%$ of all workers are employed by the industry. This field constitutes $20 \%$ of all deadly accidents and just $5 \%$ of jobs in the United States of America whereas Japan reports $30 \%$ to $40 \%$ of deaths related to this industry (ILO, 2011). The risks related to construction in developing countries are much greater, and the actual cases are three to six times higher than are reported by statistical data, indicating that the construction sites in the developing world are ten times more dangerous, than those in developed economies (ILO, 2015).

It is commonly cited that this industry boosts employment opportunities at different skill levels, ranging from laborer skills, semi skills and specialist skills. However, the construction industry suffers from many critical problems and challenges. Some of those are socio-economic stress and reduced productivity, absence of sufficient research and development, absence of sufficient safety training, evaluation of safety measures, client dissatisfaction, and ongoing rise of construction costs and pressure on profitability (Ofori, 2000; Kartam, 1998). Due to the lack of training and orientation, workers only learn from their mistakes and experience, and that increases the level of hazards. Inadequate evaluation of safety performances necessitates significant measures to establish mechanisms for the management of health and safety to prevent accidents.

Compared with other industries, construction is a perilous field owing to its distinctive nature (Jannadi \& $\mathrm{Bu}$ hamsin, 2002) and construction is normally categorized as high risk (Arnold, et al. 2019) and historically, it has been associated with a high rate of injuries and high rates of employees' death (Chan, 2011). The Labor Department in Sri Lanka states that 500,000 man-days are lost every year owing to occupational health hazards. There exists a list of occupational diseases in the country compiled by the Factories Ordinance No. 45 of 1942 and amended by Act No. 54 of 1961 and Act No. 12 of 1976. A majority of occupational hazards have not been reported because people prefer to take treatment on their own. About 102,321 victims of accidents have been treated by the Accident and Orthopedic Service of the National Hospital of Sri Lanka in 2015, and $12 \%$ of those injuries have been caused by occupational health hazards (Darshana, 2017). Fifty percent of all deadly accidents hail from the construction field (Darshana, 2017), while a majority of these accidents are preventable in nature. Therefore, it is essential that all employees who work outside their factories are adequately covered, as legal protection is constrained to those who within factory boundaries.

As per the Construction Industry Health and Safety Strategy 2004 2010, many unskilled laborers are reported within the industry, and consequently, occupational health hazards take place at a drastically 
higher rate (Zaid et. al., 2013). Given this situation, it is the responsibility of contractors and employers to make sure that sufficient welfare facilities, safety equipment and general health and safety monitoring are available (Perrenoud \& Sullivan, 2017).

Company performance-wise, it is necessary to maintain a good physical and socio-psychological environment in order to gain more productivity and reduce fundamental hazards (Owens, 2003). Eventually, the outcomes of a less healthy and safe environment may include high medical costs, large compensations, high legal cost, decline of goodwill and citizenship behavior, low efficiency, low effectiveness and low productivity (Owens, 2003).

Though, there has been studies within the context of Sri Lanka that highlighted the importance of studying accidents, illness, and diseases (Amarasinghe, 2009; Wijekoon, 2016) still such issues have not been sufficiently considered to be managed. Evident to this, Dharshana (2017) points out that the workplace health and safety have not yet been sufficiently addressed by the Ministry of Health, Nutrition and Indigenous Medicine. Arnold et al. (2019) also clearly highlights, the occupational hazards have been identified by many countries as a major cause for the health of many developing countries, yet the documented literature is scarce. This shows the insufficient literature within the study context to explain how the management of hazardous factors affect the health and safety of the workers, especially in the construction industry.
On this identified literature gap, the researchers have set the research problem of this study as: what is the impact of management of hazard factors on the employees' occupational Health and Safety in the construction industry in Sri Lanka? As the hazard factors, the researchers selected four major factors that have been highlighted within the context of Sri Lanka by Opatha (2009), citing Schuler and Youngblood (1986), that affect employees' health and safety. These factors are occupational accidents, occupational diseases, quality of work life, and occupational stress.

\section{Research Objectives}

i. To assess the level of perceived quality of health and safety and the level of management of work environmental hazards as perceived by operational employees in the construction industry.

ii. To assess the relationship between management of work environmental hazards and perceived quality of health and safety among operational workers in the construction industry.

iii. To assess the impact of management of work environmental hazards on the perceived quality of health and safety among operational workers in the construction industry. 


\section{Literature Review}

\section{Occupational Health and Safety}

Occupational safety and health (OSH) have a wide scope and is connected to several specialized fields. It focuses on: maintaining and promoting the highest level of physical, mental and social wellbeing of employees representing all jobs; the protection and preparation of workplace conditions that drop or prevent the degree of individuals being wounded as they are working; departures from health that have resulted from conditions at work; and ensuring the safety of employees from risks that pose a threat to their health and positioning them in a work surrounding that is maintained to suit their mental and physical potentials (Skeepers, 2015).

Any organization would face the problems of rising direct or indirect costs of health and safety such as medical costs, high compensation, high legal cost, high turnover, high absenteeism, low job satisfaction, decline of good will, low citizenship behavior, low efficiency, low effectiveness, low productivity, cost of delays in delivery, loss of customer satisfaction, and deaths due to the lack of quality health and safety standards (Kularathna \& Perera, 2016).

\section{Theories of Health and Safety}

Guerin and Sleet (2021) present the applicability of social and behavioral theories such as individual behaviour change theories to explain and improve occupational safety and health. AS Morris et al. (2012) reports, these theories include theory of planned behaviour (Planned Behavior TheoryPBT), which integrates theory of reasoned action and theory of perceived behavioral control that explain how individuals' cognition and attitudes, and perceived barriers that may control behavior may affect an intention to behavior in releasing an expected behaviour (see Figure 1).

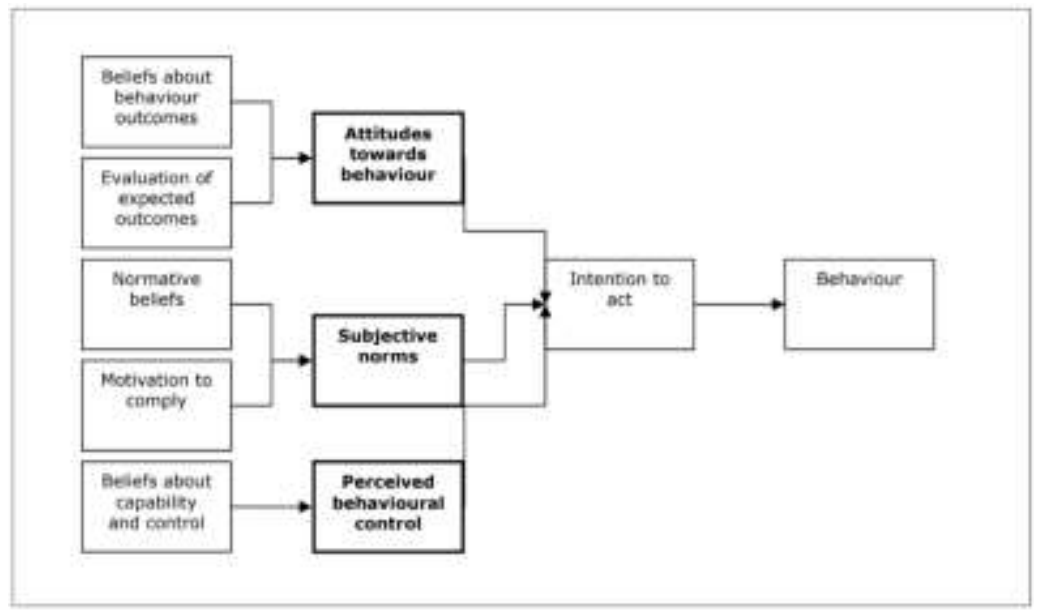

Figure 1: Theory of Planned Behaviour

Source: Morris et al. (2012) 
As explained by the PBT, the individuals' perception, formed by attitudes towards behaviour and subjective norms determine intention to act under the theory of planed behavior and theory or reasoned action. However, such intentions are further regulated by perceived behavioral controls. Availability or nonavailability of proper management of hazard factors will act as perceived controlled behaviour factor. This will regulate the perception on occupational health and safety that eventually decides employees' intention for expected behaviors that linked to organisational performance. Thus, the management of hazards factors is a key influencer for employees to perceive a healthy climate of health and safety at work that determine their high performing behaviors. This study investigates how management of hazards factors influences on employees' perception on healthy climate of health and safety at work. Other than PBT, the other individual behaviour change theories such as 'the Health Believe Model' and the 'Stage of Change' (Transtheoretical Model), and some Social and Technological Theories of Behaviour and Behaviour Change theories such as 'Social Practice Theory' and 'Diffusion of Innovation Theory' (Morris et al., 2012) can also explain the health and safety behaviors as highlighted by Guerin and Sleet (2021). Further, Morris et al. (2012) present 'the "4 E's" Model' as an integrative model for behavior and behaviour change theories by citing Government (2005) which can help further studies that broadly can explain the phenomenon under study of this research.

\section{Perceived Quality of Health and Safety}

The quality of health and safety is related to the physical and mental wellbeing of employees. However, perceptions vary from person to person as well as from subject to subject. Perception is created based on how objectives are understood, and the manner in which circumstances are interpreted. Mthalane et al. (2008) points out that an average adult spends a majority of his or her life at work, and as much as a fifth to a quarter of the variation in an adult's life satisfaction can be fulfilled via satisfaction reaped at work. Abd Rahman et al. (2016) found that workers' perception toward any subject can be measured through their attitudes related to that particular subject. The main requirements at a workplace are the clarification of general material, equipment and the supply of basic needs that portray the credibility of an organization to its employees. Disiter et al. (1990) suggest that attitudes towards basic needs and expectations are perceived as the quality of the working environment or physical, mental and emotional wellbeing by employees.

Abdullaha et at. (2009) has developed an instrument to measure this climate of health and safety as perceived by employees that deals with major areas of enabling to establish better climate for employees' health and safety that has been taken for the operationalization of the dependent variable of this study.

The availability of the health and safety management practices that were presented by Abdullaha et at. (2009) will also determine individuals' 
perception on the quality of health and safety at work. The study carried out by Mohamed (2002) emphasizes that the management of behavior-based safety climate is the grassroots level concept of achieving a safe climate. Mohamed (2002) further discovered that such health and safety climate could be established by smooth communication of health and safety measures, competence development, and supervisory support, all of which are strongly associated with the favorable health and safety context of construction sites as well. Toole (2002) portrayed a conventional design-bidconstruct project venture to assess the factors that are required to avoid the major causes of accidents and occupational hazards. Toole (2002) further showcased five kinds of capabilities that a construction company is required to formulate, namely, evaluation of site conditions, task expertise, control site, safety expertise and workers' interaction. Jannandi and Bu- Khamsin (2002) have carried out a study on site safety in the period 1976 to 1993 . As per the summary of their results, the notion of site safety is linked with distinct elements like influence of general contractors on subcontractors, site supervision, site leadership, site control, site management and site safety programmes. Furthermore, Pellicelli, (2004) demonstrated that workers who are negligent are not the main causes behind accidents; it is those who fail to manage onsite operations that act as the main reason behind accidents (Langford et al., 2000). These findings can conclude that health and safety should be established mainly with proper mechanism of hazards prevention, developing abilities or competencies to protect from hazards, and establishing sufficient protection measures from hazards. Based on these arguments, the researchers intended to study the climate of health and safety through the perceived quality of health and safety by operational workers in the construction industry, using the instrument of climate of health and safety, presented by Abdullaha et at. (2009), categorizing them under, prevention of hazards, ability to protect from hazards, and sufficiency of hazards protection.

\section{Management of Work Environmental Hazards}

Work environment Hazards are the physical and sociopsychological hazards that suddenly or slowly and cumulatively lead to the deterioration of the health and safety of an employee (Schuler \& Youngblood, 1986). Generally physical aspect covers diseases and accidents at work environment where as sociopsychological aspect covers low quality of work life and organizational stress. The term occupational hazards have been interchangeably used with the term work environmental hazards or environmental hazards.

Hazards of work environment may result in several negative outcomes. Owing to this management should understand the importance of taking necessary measures and implementing sound policies to enhance the quality of employee work environment. Formulating and implementing strategies that may ultimately result in improving work environment of employees would bring out positive outcomes such as, low medical cost, 
low compensation, increase in goodwill, low turnover, low absenteeism, increase in job satisfaction, increase in job involvement, high efficiency, high effectiveness, high productivity, etc. Furthermore, it may ultimately enhance the employees perceived quality of health and safety (Schuler \& Youngblood, 1986).

As explained by the guiding theory of PBT (see figure 1), the employee's perception on the management of 'Hazards factors' acts as 'perceived behavioral control factors'. This highlights the importance of studying about individuals' such perceptions on control factors (management of hazards), because mere focus only on attitudes and subjective norms (perceptions) about health and safety will not assure expected work behaviors or performance as individuals determines their intended behavior with the assessment of perceived behavioral control factors. This clearly justify the importance of the current study that focus on studying the influence of the management of hazards factors on the perceived quality of health and safety of the operational workers in the construction industry in Sri Lanka. Within the context of Sri Lanka, Opatha (2009) highlights four such major hazards, citing to Schuler and Youngblood (1986). They are; Occupational Accidents, Occupational Diseases, Quality of Work Life, and Occupational Stress. Occupational accidents are uncertain and sudden scenarios fueled by an external element, that results in death or an injury, and occurs as one engages in work, according to Article 3 of the
Journal of Laws, No 199, Item 1673 (CIOP-PIB. 2021).

An occupational accident can be defined as a discrete occurrence in the cause of work that results in physical or mental harm (ILO, 2013). Occupational disease is worth mentioning here that occupational disease is not a result of a particular traumatic event. It is a condition that grows with time and is determined by the nature of the job (Wrzesniewski, 1997). For example, a construction worker who raised heavy bags of cement for 10 years was detected with a tear in the knee without any particular hazardous incident to cause it, and this is known as an occupational disease (Vischer \& Wifi, 2017). Construction workers have a very high overall mortality rate, independent of social class, with bricklayers and laborers being recorded as having the second highest mortality rate (Snashhall, 2005).

Quality of work life is a measure of developing workforce and ensuring their commitment (Satpathy, 2017). Improving an employee's quality of work life is an appropriate strategy that can be used to trigger high performance in a committed workforce in order to drive the business towards a benchmark. According to Satpathy et al. (2017), creating equal systems of rewards, addressing employee job security, ensuring fulfilling careers and providing employees a role in decision making are usual parts of a quality of work life program that contains aspects like employee skill development, lowering workplace stress, job enrichment and the enhancement of cooperative labor management. 
Occupational stress is defined as the current stress linked with the place of work. Understanding the nature of an operational employee's job stress in the construction industry is important. As per Haynes and Love (2004), occupational stress among construction employees is high that can lead to unfavorable impacts such as low performance and inferior health of employees, and low productivity (Stewart \& Spencer, 2006). As an example, around $34 \%$ of the population of construction workers in Australia has been reported underwent depression, anxiety or workplace stress with a substantial rise from 1997 to 1998 (Cieslewicz, Araszkiewicz \& Sikora, 2019).

Anash (2015) emphasize the importance of managing occupational hazards, especially those in the construction sites by using tools for proper management of safety policies, procedures and practices. This should be a dynamic procedure that covers goals without resulting in "shocks" to routine business that take place in the case of accidents. Therefore, the researchers, assed the perceptions of operational employees' perception towards the management of four occupational hazards, identified in this study as the independent variable.

\section{Conceptual Framework}

In assessing the impact of the management of work environmental hazards on the perceived quality of occupational health and safety among operational employees in in the construction industry, the researchers developed the conceptual model, depicted below.

\section{Management of Work} Environmental Hazards

\begin{tabular}{|l|l|l|}
\hline Mgt of Occupational Accidents & \\
\hline Mgt of Occupational Diseases & & $\begin{array}{c}\text { Operational } \\
\text { Employees' } \\
\text { Perceived Quality } \\
\text { of Health and } \\
\text { Safety }\end{array}$ \\
\hline Mgt of Occupational Stress & \\
\hline
\end{tabular}

Figure 2: Research Framework

Source: Developed by the Authors, 2021

Based on the conceptual model, four hypotheses were developed in this study to achieve the research objectives.

\section{Hypotheses 01:}

H1: Management of occupational accidents have a positive impact on 
operational employee's perception of the quality of health and safety.

It has been found that the availability of the management of occupational accidents in construction industry that includes health and safety management skills, employers' values related to health and safety practices, and the degree of compliance with labor safety laws and regulations positively impact on employees' perception on health and safety quality (Haynes \& Love, 2004). Another study has found poor management of accidents with high rate of occupational accidents when there is an excessively low health and safety management; there is no provision of personal protection equipment to the workers; when employees are not well educated on health and safety; there is no correct use of personal protection equipment, and when workers failed to adopt safeguards or ignored hazard warning signs in the workplace (Cheng, et. al., 2010). This support that managing occupational accident would positively impact on perception on level of quality of health and safety of employees.

\section{Hypotheses 02:}

$\mathrm{H} 2$ : Management of occupational diseases have a positive impact on operational employee's perception of the quality of health and safety.

Rhee and Choe (2010) shows that worker's health is protected from occupational diseases by his/her own preventive behavior and the organizational health and safety regulations despite numerous health hazards in the workplace. Rhee and Choe (2010) further claims that ignorance of controls of occupational diseases would have a negative impact on employees' perception on quality of health and safety at work, and that every employer has an obligation to manage occupational diseases so as to enhance employee wellbeing.

\section{Hypotheses 03:}

H3: Management of quality of work life has a positive impact on operational employee's perception of the quality of health and safety.

Srivastava and Kanpur (2014) testify that a high quality of work life exists when democratic management practices are used, employee's jobs are enriched, employees are treated with dignity and safe working conditions exist and that eventually positively impact on employees' perception on occupational health and safety. Therefore, it is proven that management of quality of work life has a positive impact on employee's perception of the quality of health and safety.

\section{Hypotheses 04:}

H4: Management of occupational stress have a positive impact on operational employee's perception of the quality of health and safety.

Occupational stress is considered a risk-assessable disease. Recent highprofile litigation cases have raised awareness of the risk posed by workplace stress (Clarke \& Cooper, 2000). High risks can be effectively controlled through stress management or employee assistance programmes (Clarke \& Cooper, 2000) that eventually develop a positive perception about organization as a whole that includes perceptions on healthy climate that leads to exert their 
maximum performance (Farooqui et al., 2008). This testifies that management of occupational stress have a positive impact on operational employee's perception of the quality of health and safety.

\section{Operationalization}

Operationalization of the variables in the study is depicted in the Table 1.

\section{Table 1: Operationalization}

\begin{tabular}{|c|c|c|c|c|}
\hline Concept & Variable & Indicators & $\begin{array}{c}\text { Measurement } \\
\text { Method }\end{array}$ & Source \\
\hline $\begin{array}{l}\text { Perceived } \\
\text { Quality of } \\
\text { Health \& } \\
\text { Safety }\end{array}$ & & $\begin{array}{l}\text { Prevention of } \\
\text { accidents } \\
\text { (Management } \\
\text { Commitment, Rule } \\
\text { \& Reporting, } \\
\text { Openness in Safety } \\
\text { Communication, } \\
\text { Transition in } \\
\text { Communication) } \\
\text { Ability to protect } \\
\text { form hazards } \\
\text { (Leadership Style, } \\
\text { Role of Supervisor, } \\
\text { Training \& } \\
\text { Competence) } \\
\text { Sufficiency of } \\
\text { protection (Safety } \\
\text { Responsibility, } \\
\text { Safety Goals, work } \\
\text { duties) }\end{array}$ & $\begin{array}{l}\text { Likert scale } \\
1 \text { to } 5\end{array}$ & $\begin{array}{l}\text { Abdullaha } \\
\text { et at. } \\
(2009)\end{array}$ \\
\hline \multirow[b]{2}{*}{$\begin{array}{l}\text { Management } \\
\text { of } \\
\text { Environmental } \\
\text { Hazards }\end{array}$} & $\begin{array}{l}\text { Management } \\
\text { of } \\
\text { Occupationa } \\
1 \text { Accidents } \\
\text { (OA) }\end{array}$ & $\begin{array}{l}\text { Level of Mgt of OA } \\
\text { (Understanding } \\
\text { about Accidents / } \\
\text { employee feeling } \\
\text { about Accidents, } \\
\text { presence of safety } \\
\text { committee, employee } \\
\text { trainings) }\end{array}$ & $\begin{array}{l}\text { Likert scale } \\
1 \text { to } 5\end{array}$ & \multirow[t]{2}{*}{$\begin{array}{l}\text { Schuler and } \\
\text { Youngblood } \\
(1986)\end{array}$} \\
\hline & $\begin{array}{l}\text { Management } \\
\text { of } \\
\text { Occupationa } \\
1 \text { Diseases } \\
\text { (OD) }\end{array}$ & $\begin{array}{l}\text { Level of Mgt of OD } \\
\text { (Availability } \\
\text { Information on } \\
\text { health and safety at } \\
\text { workplace, Health } \\
\text { education program) }\end{array}$ & $\begin{array}{l}\text { Likert scale } \\
1 \text { to } 5\end{array}$ & \\
\hline
\end{tabular}




\begin{tabular}{|l|l|l|l|l|}
\hline $\begin{array}{l}\text { Management } \\
\text { of Quality of } \\
\text { work Life } \\
\text { (QL) }\end{array}$ & $\begin{array}{l}\text { Level of Mgt of QL } \\
\text { (Work life quality, } \\
\text { job security, } \\
\text { communication, } \\
\text { managers } \\
\text { understanding) }\end{array}$ & $\begin{array}{l}\text { Likert scale } \\
1 \text { to } 5\end{array}$ & \\
& $\begin{array}{l}\text { Management } \\
\text { of } \\
\text { Occupationa } \\
\text { 1 Stress (OS) }\end{array}$ & $\begin{array}{l}\text { (Workload, issues in } \\
\text { the job role, support } \\
\text { of co-workers) }\end{array}$ & $\begin{array}{l}\text { Likert scale } \\
1 \text { to 5 }\end{array}$ & \\
\hline
\end{tabular}

Source: Authors, 2021

\section{Methodology}

The population of the study is operational level employees in large sized construction firms in Sri Lanka. The target population of this study comprises blue collar employees at the operational level, such as Engineers, Supervisors, Contractors and Managers. The researchers used the Construction Industry Development Authority registry of $2018 / 19$ as the population framework and selected 15 large sized construction firms, registered in the Construction Industry Development Authority registry, which employ around 2000 operational level employees. From this population, 200 employees were chosen as the sample of the study. Hence, the sample size of this study is $10 \%$, which is a reasonable sample size, as per Lakens (2021). Minimum sample size is validated through statistical package requirement, population requirement (Saunders et al., 2009), and model requirement (Hair et al., 2010). Sampling was done using simple random sampling. Data were gathered from the sample of 200 operational level employees but only 154 employees responded satisfactorily to the questionnaires. Accordingly, the response rate of the current study is 77 per cent which is considered as a high response rate by Miller and Smith (1983). Self-administered structured questionnaire was used to collect primary data on the perceptions related to health and safety among construction workers. To test correlation and regression analyses data were analyzed using SPSS 22 package.

\section{Data Analysis}

\section{Analysis of Demographic Variables}

A large number of employees, that is, $89.6 \%$, of the sample, was male. By number,138 employees were male, and 16 employees were female. Of all employees, 48 , which is $31.17 \%$, were aged less than 35 years. Another $39.61 \%$ (61 employees) were in the age limit 36-45 years. The least percentage of $12.99 \%$ (20 employees), were above 55 years of age. A large number of employees were single $(76.6 \%)$ and only 69 were married. Analysis of employees' educational qualifications revealed that $54.5 \%$ are graduates. Analysis of work experience revealed that of 154 employees, 109 employees $(70.8 \%)$ have more than four years' experience and another $34(22.1 \%)$ employees have three to four years of work experience. Employment type 
analysis showed that of 154 respondents, 118 were employed in the permanent cadre, 21 were temporary workers, 6 were under probation, 5 were consultants and 4 were fixed term employees.

\section{Reliability Test}

As shown in Table 2, Cronbach's alpha value was tested to determine the reliability of the survey instrument. The result indicated that all the alpha values are more than 0.7 , which is the threshold value. Hence, the questionnaire was allowed to be remained as it is for the general survey.

Table 2: Reliability Test

\begin{tabular}{|l|c|c|}
\hline Variables & $\begin{array}{c}\text { Cronbach's } \\
\text { Alpha Based on } \\
\text { Standardized } \\
\text { Items }\end{array}$ & No of Items \\
\hline Mgt of Occupational accidents & 0.86 & 11 \\
\hline Mgt of Occupational diseases & 0.779 & 12 \\
\hline Mgt of Quality of work life & 0.819 & 12 \\
\hline Mgt of Occupational stress & 0.846 & 9 \\
\hline Employee's perceived quality of health and safety & 0.736 & 5 \\
\hline
\end{tabular}

Source: Field Survey, 2021

\section{Validity Test}

As presented in Table 3, the KaiserMeyer-Olkin (KMO) measure was used to assess the validity of the instrument. The KMO measure should be greater than 0.70 , and the results for all the variables proved to be greater than 0.70 . Hence, it was concluded that the study variables are correlated highly enough to provide a reasonable basis for factor analysis.

Table 3: Interpretation of Validity Test Results

\begin{tabular}{|l|c|c|c|c|c|}
\hline \multirow{2}{*}{ Variable } & \multicolumn{2}{|c|}{ Factors affecting to the Occupational } & Operational employee's \\
\cline { 2 - 6 } & Accidents & Diseases & $\begin{array}{c}\text { Quality of } \\
\text { work life }\end{array}$ & Stress & $\begin{array}{c}\text { Perceived quality of } \\
\text { Health and Safety }\end{array}$ \\
\hline $\begin{array}{l}\text { KMO Measure of } \\
\text { Sampling Adequacy }\end{array}$ & 0.773 & 0.702 & 0.724 & 0.736 & 0.748 \\
\hline Sig. Value & 0.000 & 0.000 & 0.000 & 0.000 & 0.000 \\
\hline
\end{tabular}

Source: Field Survey, 2021

Objective one: Determining the level of perceived quality of health and safety and the level of management of work environmental hazards as

Kelaniya Journal of Human Resource Management perceived by operational employees in the construction industry.

To determine the level of perceived quality of health and safety and the level of management of environmental 
hazards the cumulative mean values of the variables were analyzed.

\section{Descriptive Analysis of Variables}

The descriptive statistics of the variables of the study are as follows.

Table 4: Descriptive Statistics

\begin{tabular}{|l|r|r|r|r|}
\hline & $\mathrm{N}$ & \multicolumn{1}{|c|}{ Mean } & Std. Deviation & Variance \\
\hline OH & 154 & 9.9286 & 2.53113 & 6.407 \\
OA & 154 & 20.1429 & 4.94734 & 24.476 \\
OD & 154 & 24.2532 & 4.33946 & 18.831 \\
QWL & 154 & 23.8896 & 5.02355 & 25.236 \\
OS & 154 & 28.0519 & 6.60639 & 43.644 \\
Valid N (listwise) & 154 & & & \\
\hline
\end{tabular}

Note: OH- Perceived quality of health and safety, OA- Mgt of Occupational

Accidents, OD- Mgt of Occupational Diseases, QWL- Mgt of Quality of Work Life, OS- Mgt of Occupational Stress

Source: Data Analysis Results based on Field Survey, 2021

The results indicated that the mean of perceived quality of health and safety $(\mathrm{OH})$ is rather low (9.92). When it comes to the mean values of the four independent variables, management of occupational stress (OS) reported the highest mean value of 28.05. Mean value of management of occupational diseases (OD) is 24.25 while the mean of management of quality of work life (QWL) is 23.88. The lowest mean value of 20.14 was for management of occupational accidents (OA).

Objective Two: Determining the relationship between management of work environmental hazards and perceived quality of health and safety among operational workers in the construction industry.

To achieve objective two, correlation analysis was run, and results of the analysis is given in table 5 .
As per the analysis, four hypotheses were generated and tested based on the Pearson correlation coefficient analysis. Each hypothesis was generated to measure the degree of association between the independent variable and the dependent variable. Hypothesis 1 measured the correlation between management of occupational accidents and operational employees' perceived quality of health and safety. As per the results, the $\beta$ coefficient is 0.410 and significant at the 0.000 level in the 1-tailed statistical computation, indicating that hypothesis 1 is moderately substantiated. Hypothesis 2 measured the correlation between management of occupational diseases and operational employees' perceived quality of health and safety. As per the results, the $\beta$ coefficient is 0.260 and significant at the 0.001 level in the 1tailed statistical computation, indicating that hypothesis 2 is slightly substantiated. Hypothesis 3 measured the correlation between management of 
quality of work life and operational employees' perceived quality of health and safety. As per the results, the $\beta$ coefficient is 0.445 and significant at the 0.000 level in the 1-tailed statistical computation, indicating that hypothesis 3 is moderately substantiated. Hypothesis 4 measured the correlation between management of occupational stress and operational employees' perceived quality of health and safety. As per the result, the $\beta$ coefficient is
0.280 and significant at the 0.000 level in a 1-tailed statistical computation, and hypothesis 4 is slightly substantiated. As per the above analysis, these variables are significantly and positively correlated with each other (Independent and Dependent variables). Hence, it can be concluded that all four hypotheses are accepted, and the corresponding null hypotheses are rejected.

Table 5: Correlation Analysis

\begin{tabular}{|c|c|c|c|c|c|c|}
\hline & & $\mathrm{OH}$ & $\mathrm{OA}$ & $\mathrm{OS}$ & QWL & OD \\
\hline \multirow[t]{3}{*}{$\overline{\mathrm{OH}}$} & $\begin{array}{l}\text { Pearson } \\
\text { Correlation }\end{array}$ & 1 & $.410^{* *}$ & $.280^{* *}$ & $.445^{* *}$ & $.260^{* *}$ \\
\hline & Sig. (1-tailed) & & .000 & .000 & .000 & .001 \\
\hline & $\mathrm{N}$ & 154 & 154 & 154 & 154 & 154 \\
\hline \multirow[t]{3}{*}{$\mathrm{OA}$} & $\begin{array}{l}\text { Pearson } \\
\text { Correlation }\end{array}$ & $.410^{* *}$ & 1 & $.610^{* *}$ & $.473^{\text {** }}$ & $.491^{* *}$ \\
\hline & Sig. (1-tailed) & .000 & & .000 & .000 & .000 \\
\hline & $\mathrm{N}$ & 154 & 154 & 154 & 154 & 154 \\
\hline \multirow[t]{3}{*}{$\mathrm{OS}$} & $\begin{array}{l}\text { Pearson } \\
\text { Correlation }\end{array}$ & & $.610^{* *}$ & 1 & $.586^{* *}$ & \\
\hline & Sig. (1-tailed) & .000 & .000 & & .000 & .000 \\
\hline & $\mathrm{N}$ & 154 & 154 & 154 & 154 & 154 \\
\hline \multirow[t]{3}{*}{ QWL } & $\begin{array}{l}\text { Pearson } \\
\text { Correlation }\end{array}$ & $.445^{* *}$ & $.473^{* *}$ & $.586^{* *}$ & 1 & $.555^{* *}$ \\
\hline & Sig. (1-tailed) & .000 & .000 & .000 & & .000 \\
\hline & $\mathrm{N}$ & 154 & 154 & 154 & 154 & 154 \\
\hline \multirow[t]{3}{*}{ OD } & $\begin{array}{l}\text { Pearson } \\
\text { Correlation }\end{array}$ & $.260^{* * *}$ & $.491^{* * *}$ & $.602^{* * *}$ & $.555^{* *}$ & 1 \\
\hline & Sig. (1-tailed) & .001 & .000 & .000 & .000 & \\
\hline & $\mathrm{N}$ & 154 & 154 & 154 & 154 & 154 \\
\hline
\end{tabular}

**. Correlation is significant at the 0.01 level (1-tailed).

Note: $\mathrm{OH}-$ Perceived quality of health and safety, OA- Mgt of Occupational Accidents, OD- Mgt of Occupational Diseases, QWL- Mgt of Quality of Work Life, OS- Mgt of Occupational Stress

Source: Data Analysis Results Based on Field Survey, 2021 
Objective Three: Determining the impact of management of environmental hazards on the perceived quality of health and safety among operational workers in the construction industry.
To achieve objective three, a regression analysis was carried out as depicted in table 6.

Table 6: Model Summary - Multiple Regression Analysis

\begin{tabular}{|c|c|c|c|c|c|c|}
\hline & \multirow[t]{2}{*}{ Model } & \multicolumn{2}{|c|}{$\begin{array}{l}\text { Unstandardized } \\
\text { Coefficients }\end{array}$} & \multirow{2}{*}{$\begin{array}{c}\begin{array}{c}\text { Standardized } \\
\text { Coefficients }\end{array} \\
\text { Beta }\end{array}$} & \multirow[b]{2}{*}{$\mathrm{T}$} & \multirow[b]{2}{*}{ Sig. } \\
\hline & & B & Std. Error & & & \\
\hline \multirow[t]{5}{*}{1} & (Constant) & .423 & 1.454 & & .291 & .772 \\
\hline & $\mathrm{OA}$ & .357 & .042 & .308 & 3.754 & .000 \\
\hline & OD & .202 & .052 & .003 & .037 & .007 \\
\hline & QWL & .153 & .044 & .304 & 3.508 & .001 \\
\hline & OS & .394 & .028 & .245 & 3.405 & .001 \\
\hline
\end{tabular}

a. Dependent Variable: $\mathrm{OH}$

Note: $\mathrm{OH}-$ Perceived quality of health and safety, OA- Mgt of Occupational Accidents, OD- Mgt of Occupational Diseases, QWL- Mgt of Quality of Work Life, OS- Mgt. of Occupational Stress Source: Data Analysis Results Based on Field Survey, 2021

As per the above regression analysis, the influence of each independent variable (Management of occupational accidents, management of occupational disease, management of quality of work life and management of occupational stress) on the perceived quality of health and safety, the beta values are considered by ignoring the unfavorable signs. These beta values were recorded as $0.357,0.202,0.153$, and 0.394 respectively. Thus, the highest beta value 0.394, which represents the most powerful contribution to the dependent variable is the management of occupational stress that has the greatest impact on the quality of health and safety practices as perceived by the employees.

\section{Discussion}

The results of the present study provide answers to the three research questions. Accordingly, the first research question was to determine the level of perceived quality of health and safety and the level of management of environmental hazards as perceived by the operational employees in the construction industry. As per the results, the level of perceived quality of health and safety was relatively low. This could be mainly due to the hazardous nature of the construction industry. The finding was further confirmed by the study conducted by Farooqui et al. (2008), which confirms construction industry as one of the most hazardous industries. Hence, employees perceived that the quality of health and 
safety in this industry is relatively low compared to other industries (Farooqui et al., 2008).

When considering the level of management of; occupational accidents, occupational diseases, quality of work life and occupational stress, all these factors reported a high level of cumulative mean values. This confirms that in the construction industry, employees relatively perceive a good management of hazards by the companies.

The second research question was to determine the relationship between management of environmental hazards and perceived quality of health and safety among operational workers in the construction industry. The result of the present study demonstrated that there are significant relationships between the two, as evident by the results of the correlation analysis between the management of environmental hazards and operational employees' perceived quality of health and safety. This indicates that, according to employees' perception, the selected organizations are highly concerned about the management of environment hazards and has implemented necessary health and safety measures within organizations. As a result, employees' responses show that they are satisfied with their working environment. This indicates that the construction industry has well aware of what Quartey and Puplampu (2012) claims that poor management of hazards will eventually leads to develop a negative perception about the quality of health and safety practices with an industry.

Kelaniya Journal of Human Resource Management
As per the findings, the highest significant relationship is between management of occupational stress and perceived quality of health and safety. This explains that employees consider managing their mental stability as the most important aspect when it comes to health and safety, and the well management of employees' stress positively correlates their perception on the quality of health and safety. Same result has been found in the study of Farooqui et al. (2008) that confirms that employees are more concerned about maintaining a proper mental health in order to perform well. Clarke and Cooper (2000) have also pointed out the importance of managing occupational stress, which is considered as a risk-assessable disease. Recent high-profile litigation cases have raised awareness of the risks posed by workplace stress.

Occupational accidents have the second highest significant relationship with the perceived quality of health and safety. This is mostly because management has paid more attention to prevent or minimize accidents than to other factors. As per the findings, it can be concluded that management has taken necessary action by setting strict rules and regulations. The findings in the literature also reveal that employees also take steps to prevent accidents, and so, they often adhere to the rules and regulations set by the organization. As per Haynes and Love (2004) management of occupational accidents in construction enterprises develop positive perception about health and safety climate by practices such as developing health and safety management skills, employers' values related to health and safety practices, 
and the degree of compliance with labor safety laws and regulations.

As per the findings occupational diseases has the third highest impact on quality of health and safety perception of employees. Rhee and Choe (2010) also stated the importance of managing occupational diseases. They have highlighted that workers' health may be protected from occupational diseases by their own preventive behavior, despite numerous health hazards in the workplace. Not managing occupational diseases well would have a negative impact on employees' perception on quality of health and safety at work (Rhee \& Choe, 2010). Consequently, the findings of the current study comply with the findings of Rhee and Choe (2010).

Study also found a significant relationship between the management practices related to the quality of work life, and the perception of quality of health and safety. Therefore, these employees believe that factors affecting to their quality of work life are managed well in the organization in which they work. Quality of work life has been identified as one of the major aspects when it comes to work environment. Smallwood et al. (2008) found that positive perception on health and safety practices are mostly based on the quality of work life. In their study this was found to be the most important element when it comes to the management of environmental hazards. But current study found quality of work life as the factor which has the lowest significance, compared to other three hazards. This is mostly due to the contextual difference in the studies. As Smallwood et al. (2008) has carried out their study in the South African context those employees may consider management of quality of wok life as the major factor to determine the quality of health and safety. Within Sri Lankan context, employees may concern more about management of occupational stress, accidents and diseases to determine the quality of health and safety.

\section{Conclusion}

This research concluded that the management of work environment hazards impacts on the employees' perceived quality of health and safety in the construction industry in Sri Lanka even though the perceived quality of health and safety within industry is relatively low in spite of sufficient management efforts have been taken to manage work environmental hazards. This further concludes that the organizations in the construction industry should take more actions on managing occupational deceases and enhancing quality of work life of employees though they have taken satisfactory management initiatives in managing occupational stress and accidents.

\section{Implications}

This understanding is important as such perceptions of employees regarding hazards and health and safety in an industry like construction will leads their intended actions such as motivation to work, putting extra efforts, retaining within the industry or leaving the industry, meeting performance targets, and finally their feelings about work satisfaction. Such intentions of employees will ultimately lead organizations' and industry's 
overall performance and sustainability. This bring lights to the management decision makers to seriously apply the individual behaviour change theories such as Panned Behavior Theory (PBT) described here above.

For the practitioners and the management decision makers, this study findings implicate in planning and execution of work environmental hazards management policies and health and safety protocols.

For the researchers, this study implies new areas to investigate more factors other than the selected four factors of this study as this study showed that employees have been relatively satisfied with the management of the selected four hazards though they are not satisfied with the existing health and safety climate.

\section{Recommendations}

As this study implicated with management considerations towards hazards, and health and safety climate that can determine employees' intended behaviors that eventually decides the delivery of construction firms, the top management should rightly empower the HRM of these organization to rightly set policies, decide interventions and implement actions in order for managing hazards and developing a right health and safety climate. Further, HRM should be empowered with doing research on these critical areas rather depending on traditional research agendas on health and safety. This demands high quality HR professionals to the industry with the right maturity in academic rigor and practical exposure.
When practicing hazards management policies health and safety protocols by the management in the construction industry, the industry should benchmark best practices as suggested by the relevant institutional protocol developers such as ILO, and the world best companies in the construction industry around the globe.

This demands effective learning and knowledge sharing interventions across companies with the industry locally and globally to which, supports to be claimed from the local governments and international NGOs and organizations. Closely working with the universities and other relevant institution is essential in deciding the right actions and policies regarding the phenomena in concern. Construction companies need to promote the continuous improvement of workplace health and safety standards, and it is crucial to make sure that all workers comply with the company health and safety policies and regulations and ensure technical and social progress in the field of construction. Promotion of health and safety in the industry at all levels is crucial for workplace health practice and efforts are required to improve the physical, mental and social well- being of employees attached to construction companies based in Sri Lanka. The Government could prepare a training manual in relation to the safety of staff members and formulate training platforms in every construction company based in Sri Lanka. This industry needs to enroll its operational staff members in forums that discuss and seek to address the problems they encounter in relation to their own safety. 


\section{Limitations and Suggestions for Future Research}

The study was limited to major players within the industry and the medium and small-scale players were not considered. Besides, the selected hazards factors were quantitatively studied using survey methods that tried to corroborate theoretical insights, taken from foreign contexts. Further, possible mediators and moderators were not considered in the current study. Application of other relevant theories such as 'Health Believe Model' and '4E Model' would generate more varied results.
On this ground the researchers direct further research to study plausible hazards factors qualitatively within the construction industry in Sri Lanka as a unique context that can induce more varied context dependent and more practical hazard factors that might have already affected health and safety clime. Extension of the same study into other small and medium players is another possible further study area, perhaps considering relevant moderators and interveners as well. Extending similar kind of studies using more varied theories will lead more fruitful research in the same field.

\section{References}

Abd Rahman, N., Goh, K. C., Goh, H. H., Omar, M. F., Toh, T. C., Mohd Zin, A. A., Mohd Jaini, Z., Yunus, R., \& Rahmat, S. N. (2016). Accidents preventive practice for high-rise construction. MATEC web of conferences, 47, 1-6.

Abdullaha, A.C., Spickettb, J.T., Rumchevc, K.B., and Dhaliwald, S.S. (2009). Validity and Reliability of the Safety Climate Measurement in Malaysia, International Review of Business Research Papers, 5 (3), p. 11-141

Amarasinghe, N. (2009). Importance of reporting accidents and illness. National safety conference on "safety work promotes healthy life". Colombo.

Ansah, E.W. (2015). Analysis of occupational health and safety, accident and safety, safety measures and disease prevention, doi:10.13140/rg.2.2.36203.13602

Arnold, S.M., Wickrematilake, M.S.K., Fernando, R.M.S.D. (2019). Occupational hazards in medium and largescale industrial sectors in Sri Lanka: experience of a developing country. BMC Res Notes 12, 755. https://doi.org/10.1186/s13104-019-4790-2

Chan, M. (2011). Fatigue: The most critical accident risk in oil and gas construction. Construction Management and Economics, 29 (4), 341-353.

Cheng, C.W., Leu, S.S., Lin, C.C., \& Fan, C. (2010). Characteristic analysis of occupational accidents at small construction enterprises. Safety Science, 48 (6), 698-707.

Cieslewicz, W., Araszkiewicz, K., \& Sikora, P. (2019). Accident rate as a measure of safety assessment in Polish civil engineering. Safety, 5 (4), p.77. 
CIOP-PIB. (2021). Accidents at work. [ONLINE]. https://www.ciop.pl/CIOPPortalWAR/appmanager/ciop/en?_nfpb=true\&_pa geLabel=P18600139121365512930443\&html_tresc_root_id=15877\&html_tr esc_id=15898\&html_klucz=15878. [Accessed 2 June 2021].

Clarke, S.G., \& Cooper, C.L. (2000). The risk management of occupational stress. Health, risk \& society, 2 (2), 173-187.

Darshana, W.D. (2017). Improvement of health and safety in construction sites in Sri Lanka. Engineer: Journal of the Institution of Engineers, Sri Lanka, 1(50), 53-70.

Deacon, C. H., \& Smallwood, J. (2017). The effect of the integration of design, procurement, and construction relative to health and safety (Doctoral dissertation, Nelson Mandela Metropolitan University).

Dister, E., Gomer, D., Obrdlik, P., Petermann, P., \& Schneider, E. (1990). Water management and ecological perspectives of the upper rhine's floodplains. Regulated Rivers: research \& management, 5 (1), 1-15.

Farooqui, R.U., Arif, F., \& Rafeeqi, S.F.A. (2008). Safety performance in Construction Industry of Pakistan. International Conference on Construction in Developing Countries, Karachi, Pakistan.

Guerin R.J., and Sleet D. A. (2021). Using Behavioral Theory to Enhance Occupational Safety and Health: Applications to Health Care Workers. American Journal of Lifestyle Medicine. 15 (3). 269-278. doi:10.1177/1559827619896979

Hair, J.F., Black, W.C., Babin, B.J., \& Anderson, R.E. (2010). Multivariate Data Analysis (7th ed.). New York: Pearson.

Haynes, N. S., \& Love, P. E. (2004). Psychological adjustment and coping among construction project managers. Construction management and economics, 22 (2), 129-140.

International Labour Office (ILO). (2011). introductory report: Global trends and challenges on occupational safety and health: XIX World Congress on Safety and Health at Work: Istanbul, Turkey, 11-15 September 2011, 19th World Congress on Safety and Health at Work Istanbul, Turkey, (Geneva), p. 53.

International Labour Organization. (2015). Construction: A hazardous Work. https://www.ilo.org/safework/areasofwork/hazardouswork/WCMS_356576/lang--en/index.htm 
International Labor Organization. (2013). Global Employment Trends 2013: Recovering from a second jobs dip. https://www.ilo.org/wcmsp5/groups/public/---dgreports/---dcomm/--publ/documents/publication/wcms_202326.pdf

International Labour Organization. (2021). Occupational Safety and health: World Statistics. https://www.ilo.org/moscow/areas-of-work/occupational-safetyand-health/WCMS_249278/lang--en/index.htm [Accessed 21 September 2021].

Jannadi, O. A., \& Bu-Khamsin, M. S. (2002). Safety factors considered by industrial contractors in Saudi Arabia. Building and Environment, 37 (5), 539-547.

Kartam, N. A., \& Bouz, R.G. (1998). Fatalities and injuries in the Kuwaiti construction industry. Accident analysis \& prevention, 30 (6), 805-814.

Kularathna, W. K. H. U., \& Perera, G. D. N. (2016). The impact of safety and health on job satisfaction in selected branches of utility service supply organization in western province north in Sri Lanka. 3rd International HRM Conference.

Lakens, D. (2021). Sample Size Justification. https://doi.org/10.31234/osf.io/9d3yf

Langford, D., Rowlinson, S., \& Sawacha, E. (2000). Safety behaviour and safety management: its influence on the attitudes of workers in the UK construction industry. Engineering, Construction and Architectural Management.

Miller, L.E., \& Smith, K.L. (1983). Handling Non Response Issues. Journal of Extension, 21, 45-50.

Ministry of Labour and Labour Relations. (2011). National occupational Health and Safety Policy.

http://www.health.gov.lk/moh_final/english/public/elfinder/files/publications /publishpolicy/25_Occupational\%20Safety\%20Policy.pdf

Mohamed, S. (2002). Safety climate in construction site environments. Journal of construction engineering and management, 128 (5), 375-384.

Morris, J., Marzano, M., Dandy, N., and O'Brien, L. (2012). Theories and Models of Behaviour and Behaviour Change, Forest Research, https://www.forestresearch.gov.uk/documents/1409/behaviour_review_theor y.pdf

Mthalane, D., Othman, A. A. E., \& Pearl, R. G. (2008). The economic and social impacts of site accidents on the South African society. Proceedings of the 5th post graduate conference on construction industry development. 
Ofori, G. (2000). Challenges of construction industries in developing countries: Lessons from various countries. International conference on construction in developing countries, 5 (24), 15-17.

Opatha, H. H. D. N. P. (2009). Human Resource Management: Personnel. Colombo: Department of HRM, University of Sri Jayewardenepura

Owens, P. (2003). Accidents Don't Just Happen: The Liberal Politics of HighTechnology Humanitarian' War. Millennium, 32 (3), 595-616.

Pellicelli, A. C. (2004). Strategic Alliance-Economia Aziendale.

Quartey, S.H., \& Puplampu, B. B. (2012). Employee Health and Safety Practices: An Exploratory and Comparative Study of the Shipping and Manufacturing Industries in Ghana. International Journal of Business and Management, $7(23)$

Rhee, K.Y., \& Choe, S.W. (2010). Management system of occupational diseases in Korea: statistics, report and monitoring system. Journal of Korean medical science, 25 (Suppl), 119.

Satpathy, S., Dash, S. R., \& Mahapatra, J. (2017). Towards Understanding Motivational Variables of Employee Retention in Present Indian Scenario. International Journal of Applied Business and Economic Research 15 (19), 343-356.

https://www.researchgate.net/publication/339712651_Towards_Understandin g_Motivational_Variables_of_Employee_Retention_in_Present_Indian_Scen ario

Saunders, M., Lewis, P., \& Thornhill, A. (2009). Research Methods for Business Students. New York: Pearson.

Schuler, R.S., \& Youngblood, S. A. (1986). Effective personnel management. West Publishing Company.

Skeepers, N.C. (2015). Safety leadership and management in the construction industry in Gauteng Province, South Africa (Doctoral dissertation, University of Johannesburg).

Smallwood, J., Haupt, T., \& Shakantu. (2008). Construction health and safety in South Africa: Status and recommendations. CIDB report.

Snashall, D. (2005). Occupational health in the construction industry. Scandinavian journal of work, environment \& health, 5-10.

Srivastava, S., \& Kanpur, R. (2014). A study on quality of work life: key elements \& its Implications. IOSR Journal of Business and Management, 16 (3), 54-59. 
Stewart, R. A., \& Spencer, C. A. (2006). Six -sigma as a strategy for process improvement on construction projects: a case study. Construction Management and Economics, 24 (4), 339-348.

Toole, T.M. (2002). Construction site safety roles. Journal of construction engineering and management, 128 (3), 203-210.

Vischer, J.C., \& Wifi, M. (2017). The effect of workplace design on quality of life at work. Handbook of environmental psychology and quality of life research, $387-400$

Wijekoon, A.W.M.B. (2016). Significant workplace injuries and decease in Sri Lanka. Electronic Thesis and Dissertation. University of Moratuwa Sri Lanka, http://dl.lib.uom.lk/bitstream/handle/123/12321/fullthesis.pdf? sequence $=2 \&$ is Allowed $=$ n

Wrzesniewski, A., McCauley, C., Rozin, P., \& Schwartz, B. (1997). Jobs, careers, and callings: People's relations to their work. Journal of research in personality, 31(1), 21-33. 